Received on (14-11-2019) Accepted on (26-02-2020)

\section{A New Historicist Reading of William Shakespeare's Julius Caesar: Representation of Roman History in Light of Renaissance Culture and History}

Main Researcher :

Muna Mohamad Abd-Rabbo

1 University Name \& City

Arts Al-Zaytoonah University of Jordan / Amman

E-mail address: anumra@yahoo.com

\title{
Abstract:
}

William Shakespeare borrows extensively from Thomas North's translation of Plutarch's The Lives of Noble Grecians and Romans (1579) in the drama Julius Caesar (1599). At the same time, Shakespeare adapts, manipulates and reworks historical facts to accommodate his Elizabethan surroundings. In this paper, the play Julius Caesar is analyzed in reference to its historical source, Plutarch's The Lives of Noble Grecians and Romans, and within the theoretical framework of New Historicism. A review was conducted of various studies pertaining to the historical background of the play Julius Caesar. Some of these researches focus on the similarities and differences between Shakespeare's play and Plutarch's historical narrative while other sources highlight aspects of the play which are characteristic of Elizabethan thought rather than Roman culture. The general approach in this research has been a comparative one; a scene by scene correlation was carried out between the play on one hand and Plutarch's historical account of the circumstances surrounding the assassination of the Roman ruler on the other. Furthermore, this research briefly touches upon Shakespeare's motives for making historical modifications. Such motives include dramatic economy, theatrical effects and factors relating to the playwright's contemporary matters.

Keywords Shakespeare, Julius Caesar, Plutarch, New Historicism, Elizabethan Age, Roman History

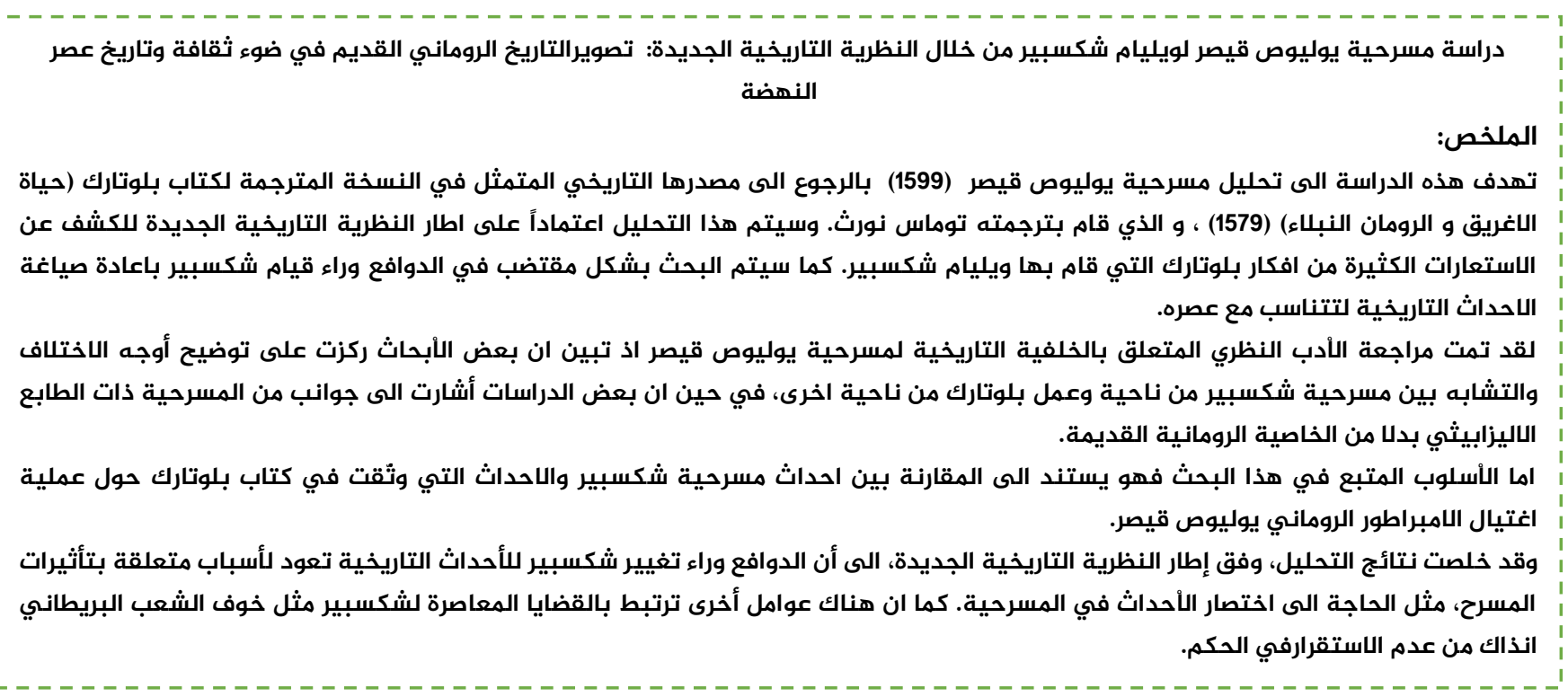




\section{INTRODUCTION:}

William Shakespeare relies heavily on Thomas North's translation of Plutarch's The Lives of Noble Grecians and Romans (1579) in the making of Julius Caesar (1599). Numerous parallels emerge between the two narratives regarding the assassination of the Roman emperor and the events leading up to and following this historic event. However, Shakespeare's originality appears in his ability to manipulate, alter and adapt the historical narrative to suit the Elizabethan stage. The Elizabethan playwright does not commit himself entirely to the Classical Roman context, but rather his artistic license permits him to modify the historical context in order to dramatize the story of the emperor, rendering it more compatible with Elizabethan drama; moreover, he addresses various political issues pertaining to sixteenth century England. Thus, the play seems to create a Roman milieu, but, at the same time, it encompasses numerous Renaissance thoughts, sentiments and notions.

This study provides a New Historicist analysis of the extent to which Shakespeare abides by and departs from historical facts. Furthermore, the research embarks upon an exploration of the play's reflection of the dramatist's Elizabethan background. The research methodology has been a comparative one in which a scene by scene scrutiny was conducted of both Shakespeare's Julius Caesar and Plutarch's historical narrative of Caesar's death. It is known that Shakespeare differs considerably from Plutarch not only in his representation of history, but also in his depiction of the historical figures in the play, namely Caesar and Brutus. The discrepancies between the two narratives are explored from a New Historicist angle. Moreover, this research addresses Shakespeare's objectives behind the historical alterations; such objectives include dramatic economy, theatrical purposes and issues concerning the Elizabethan age, namely the socio-political upheavals of the Renaissance with its conflicts, monarchal vacuum and cultural / religious splits.

In this research I have attempted to trace all the historical / cultural variations between Shakespeare's Julius Caesar and Plutarch's The Lives of Noble Grecians and Romans by adopting a New Historicist angle. The main approach to my analysis has been a textual comparison and contrast between the two works in order to highlight Shakespeare's integration of Elizabethan cultural, social and political components with Roman historical and cultural elements.

\section{New Historicism in Brief:}

New Historicism delves into the historical, cultural and ideological realities surrounding any given literary work. This theory which emerged in the 1980s and gained more prominence in the 1990 s, does not concern itself with the historical accuracy of the events portrayed in literature, but rather it seeks to reveal a literary work's social, cultural and political implications with regard to its historical background. The theoretical focal point of New Historicism has been "its heightened critical awareness not only of the historicity but also of the textuality of culture" (Meyer, 2014, p. 592), or as Stephen Greenblatt (1989) puts it, the "poetics of culture" (p. 1).

New Historicists have greatly altered the traditional view of history; it is no longer portrayed as a fixed entity, but rather it is seen as an ever-changing space wrought with never-ending clashes. In New Historicism the past is visualized as "uneven, fragmented, even unfinished so that history is a site of conflict which is ongoing, not a stable form of containment" (Webster, 1990, p.116). Moreover, the impact that literature has on the representation of history has come under scrutiny. New Historicists have played a vital role "in rethinking or deconstructing the kind of assumptions made about the past and literature's place in it, particularly with regard to Shakespeare and the Elizabethan period" (Webster, 1990, p. 116). Literature is no longer simply a reflection of culture; instead, works of literature are construed as an intrinsic element in the shaping and fashioning of cultural thought and practices. Individual literary texts are considered an integral component in the "circulation of social energy" (Greenblatt, 1988, p. 2) that creates and recreates an infiniteness of historicity. 


\section{New Historicism and Shakespeare:}

In Renaissance Self-Fashioning: From More to Shakespeare (2005), the prominent New Historicist Stephen Greenblatt explores Shakespeare's relationship to the Renaissance culture. Shakespeare's plays offer a representation of the Elizabethan mindset; furthermore, his works present a reflection upon the age's inner social workings.

According to Greenblatt (2005):

Shakespeare's language and themes are caught up, like the medium itself, in unsettling repetitions, committed to the shifting voices and audiences, with their shifting aesthetic assumptions and historical imperatives that govern a living theatre. (p. 254)

Both history and literature are flux in nature, intertwining within a fluctuating sphere, governed by the variations in the social, cultural, ideological and political forces. The socio-political turmoil of the Renaissance with its power struggles, monarchal vacuum and cultural / religious divides are rendered tacitly in Julius Caesar. Consequently, New Historicists focus in their studies on the age of the Renaissance and its rich texture of cultural complexities as well as its conflicting political and religious components.

Richard Strier (1982) analyses Greenblatt's choice of the sixteenth century in order to explore "the creation and representation of selves" (Strier, 1982, p. 384), explaining that:

...he [Greenblatt] sees the sixteenth century as the first period in England in which there was a large scale sense of human identity as open to both social and individual shaping. (Strier, 1982, p. 384)

The Renaissance was an age of discoveries and developments in art, science, religion and culture. In addition, it witnessed a shift from the focus on the Afterlife, as had been the case in the medieval age, to a more in depth concern with the Here and Now. Individuals from this age saw the human potential for development; therefore, the science of humanism appeared with its emphasis on human interests, developments and values (Raspa, 2016; Hadfield, 2014).

The characters in Shakespeare's plays achieve a great sense of selfhood and individuality; at the same time, these characters are molded by the social forces surrounding them. As Sharon O'Dair points out (1993), Shakespeare's characters "express some sense of separation from roles, from public activity, from definition by the group"; however, these characters are constantly "developing within and because of the context of others" (O’Dair, 1993, p. 289).

The dialectics of selfhood and public life are manifested in the behavior of both Caesar and Brutus on more than one occasion. Caesar achieves enormous heights of god-like grandeur due to the support of the masses and the majority of the senators. Furthermore, Caesar's decision to go to the senate on the day of his assassination despite Calpurnia's pleas not to do so is strongly induced by his fear of public disapproval. On the other hand, Brutus is manipulated by Cassius to join the conspiracy when the latter demonstrates the public's expectations of Brutus to rescue them from Caesar's tyranny. The honorable title that defines Brutus has been bequeathed upon him by the society surrounding him, and it is this key circumscribing trait that motivates him to betray his friend in an ironic, out-of-character, dishonorable act.

Shakespeare's England witnessed a myriad of alterations at the political, cultural, ideological and humanistic level. At the same time, the Elizabethan age was plagued by political anxieties and civic unrest. In that regard, Julius Caesar is viewed as a reflection of the time's "widespread fear that the queen would be overthrown and that the country would be thrown into...civil and religious war" (Kewes, 2002, p. 155). Therefore, it dramatizes "the danger of a disputed succession and the horrors of civil war" (Kewes, 2002, p. 155). Consequently, Shakespeare implicitly captures the general turmoil that marked the Renaissance at the political, social and religious levels in his creation of an ancient Roman interpretation of his contemporary world. Therefore, Shakespeare does not wholly bind himself to the historical sources available to him, but 
rather he ventures out of the realm of historical accuracy and adorns his Roman tale with Renaissance variations.

\section{Shakespeare's Historical Sources for Julius Caesar:}

In his book The Sources of Shakespeare's Plays, Kenneth Muir (1977) investigated Shakespeare's utilization of North's translation of Plutarch in writing Julius Caesar. The first three acts are derived from Plutarch's portrayal of the three Lives of Caesar, Antony and Brutus while the rest of the play is predominantly taken from the Life of Brutus. Nevertheless, Shakespeare does not entirely commit himself to the historical facts as they are presented in Plutarch for the sake of "dramatic economy" (Muir, 1977, p. 117). Historically speaking, there is a period of four months between Caesar's victory over Pompey's sons and the feast at Lupercal; in addition, the tribunes' disrobing of Caesar's statues takes place later in the projected coronation. In the opening scenes in Julius Caesar, however, these dispersed events are compacted into one day.

In an online article, Jackson (2000) demonstrates how Shakespeare reworks chronology in order to make events more suitable for a stage drama. Plutarch placed Julius Caesar's victory over Pompey's sons in 45BC, and the setting up of the new triumvirate in 42BC. Shakespeare compresses the events of these three years into five fully packed days. Shakespeare makes numerous changes, adding incidents, deleting others and even distorting the historical order of certain occurrences all to achieve suspense and "invigorate the tale with uncertainty", especially since Plutarch offers no ambiguity or suspense.

C.J. Ronan (1983) took up the issue of the victory celebrated in the opening scene of the play. Historically speaking, Caesar defeated Pompey's sons Sextus and Gnaeus in 45 BC. However, Shakespeare's phrase "Pompey's blood" (I, i, 50) seems to allude to Pompey the Great himself and not his sons. Ronan (1938) argued that Shakespeare apparently creates this ambiguity about who Caesar triumphed over in order to achieve a heightened dramatic effect because "Pompey's sons are of no interest to the popular imagination" (p. 11) unlike Pompey, Caesar's renowned enemy.

Another considerable deviation for Shakespeare from Plutarch is the playwright's portrayal of Julius Caesar as an emperor. Patrick Gray (2016) explains how Shakespeare models his version of the emperor Julius Caesar based upon "the conventional depiction of Julius Caesar's successor Augustus, as well as other tyrants such as Herod the Great in medieval English mystery plays" (Gray, 2016, p. 1). While Plutarch paints a picture of the Roman emperor as a "shrewd, resilient and relatively dignified individual" (Gray, 2016 p. 1), Shakespeare contrastingly presents the audience with a "physically weak and surprisingly obtuse" (Gray, 2016, p.1) leader oftentimes "prey to laughable grandiosity" (Gray, 2016, p. 1).

Shakespeare's unconventional depiction of Caesar may arise from the political upheaval rampant during the Renaissance as well as the growing fears of the potential political vacuum that may result from the overthrow of the monarchy. Shakespeare's Julius Caesar is presented as a more humanized character with numerous faults, be they physical or otherwise. Such a portrayal lies in sharp contrast to the larger- than- life Emperor depicted in Plutarch. Shakespeare perhaps aims to render Caesar more worthy of the audience's sympathy and even more believable as a victim of betrayal and injustice. Maybe for Shakespeare, Julius Caesar, with all his flaws, remains the lesser of two evils for the Romans, the second evil manifested in the impending political strife and civil unrest that accompany any toppling of a sovereign leader.

\section{Shakespeare and Plutarch: Differences in Narration: The Feast at Lupercal}

The account given in Plutarch of the events that transpire in the Lupercal festival differs slightly from Shakespeare's depiction of the same occasion. According to Plutarch (1579 / 1999), Caesar refuses the crown three times and is unhappy that the people applaud his refusal. In the meantime, the two tribunes Flavius and Marullus remove all the royal diadems that had been placed on the statues of Caesar. Caesar is angered by their actions and dismisses them from their offices. 
Caesar makes a speech condemning the two tribunes and speaks disrespectfully of the common people.

In Shakespeare's Julius Caesar, Caesar falls ill after he sees that the commoners are opposed to his proposed coronation. Casca, reporting what had happened in the festival states that Caesar "fell down in the market place and foamed at the mouth and was speechless" (I, ii, 249-50). In the play Caesar is portrayed as being closer to the people; he does not speak ill of them as he does in Plutarch, but he does cast off Flavius and Marullus for disrobing his images.

In Plutarch, the revolutionaries who oppose Caesar's coronation see the incident at the Lupercal Festival as a threat to Roman democracy and as a sign of Caesar's dictatorial tendencies. Therefore, they turn to Brutus as a possible defender of democracy, especially since it was his ancestor who had ousted the last dictator of Rome. After joining the conspirators, Plutarch pointed out that Caesar had his doubts about Cassius, and he once asked some friends what they thought of Cassius. Caesar adds "I'm not keen on him myself: he's too pale" (Plutarch, 1579 / 1999, p. 352). In another situation when someone accuses Antony and Dolabella of turning against him, Caesar responds saying 'I'm not afraid of these overweight, long-haired men, so much as those pale, lean ones" (Plutarch, 1579 / 1999, p. 352). Plutarch even suggested that the pale, lean men Caesar speaks of not only include Cassius but Brutus as well.

In Shakespeare's play, however, it is never implied that Caesar ever suspects Brutus of any foul play. He makes similar remarks about Cassius as he does in Plutarch. When Caesar returns from the Lupercal Festival he tells Antony:

Let me have men about me who are fat

Sleek- headed men, and such as sleep o'night

Yond Cassius has a lean, and hungry look.

He thinks too much; such men are dangerous (I, ii, 192-5)

In Background of Shakespeare's Thoughts, Hankins (1978) proposed that Shakespeare was influenced by the Renaissance theory of the humors. In fact, Cassius is an example of the "cholericmelancholy" (Hankins, 1978, p.128) man. His leanness and greediness are in line with the features of a choleric man; his pensiveness, lack of sleep and his broad reading characterize the melancholic man. On the other hand, Antony is an example of the "sanguine man" while Brutus is the "wellbalanced man in the play" (Hankins, 1978, p.128). Shakespeare's characterization of Cassius, Antony and Brutus in light of Elizabethan thought explicates the playwright's ingenuity in merging his audience's background with Roman history. He takes a statement made by the historical Caesar and gives it a Renaissance elucidation. In such a manner, Shakespeare is able to bring these characters closer to his spectators' perceptions and mindset.

\section{Events Leading up to the Assassination:}

In Plutarch, Cassius and Brutus become more determined than ever to implement Caesar's assassination for the sake of Roman democracy. After gathering a sufficient number of allies, the two conspirators begin to plan Caesar's murder. Antony's name is suggested as a possible recruit, and all the conspirators approve of this choice. However, Trebonius rejects Antony because he had approached Antony about such an act rather "delicately and cautiously" (Plutarch, 1579 / 1999, p. 374). Antony had got the gist of what Trebonius was suggesting, but refused to be part of any action against Caesar. At the same time Trebonius adds that Antony "had not denounced them, but had faithfully kept the conversation to himself" (Plutarch, 1579 / 1999, p. 374). Afterwards there is a debate amongst the conspirators about whether Antony should be put to death after Caesar's assassination, but Brutus persuades them not to kill Antony because as he argues "any deed which is taken for the sake of law and justice must be pure and untainted by injustice" (Plutarch, 1579 / 1999, p. 374). 
In Shakespeare, Antony's name never emerges as a possible member of the revolution against Caesar. Some of the conspirators feel that Antony must be killed after Caesar's death just as they do in Plutarch. Cassius states that:

...I think it is not meet,

Mark Antony, so well beloved of Caesar,

Should outlive Caesar; we shall find of him

A shrewd contriver (II, I, 155-8).

Just as in Plutarch, Brutus prevents Antony's death by uttering similar noble words. He affirms his belief in the purity of their intentions in this statement:

Let us be sacrificers, but not butchers, Caius.

We all stand up against the spirit of Caesar,

And in the spirit of men there is no blood...

We shall be called purgers, not murderers.

And for Antony, think not of him;

For he can do no more than Caesar's arm

When Caesar's head is off (II, I, 165-83).

The critic Kaula (1981) drew attention to the religious content of the assertion above. In Plutarch, Brutus does not give Caesar's assassination any religious dimensions. Quite the contrary, he merely focuses on the good of the state. Therefore, Kaula (1981) views Brutus' religious language as an indicator of how Shakespeare applies "contemporary religious notions to Rome" (p. 198). It is one of Shakespeare's additions to the historical account "to have Brutus conceive the assassination as a controlled and dignified ritual, a sacrifice or offering to the gods" (Kaula, 1981, p. 197).

The preceding discussion of Caesar's assassination by the conspirators is just one occasion where Shakespeare refers to "matters out of keeping with the Pre-Christian setting" (Kaula, 1981, p. 197). At numerous times, the characters in the play express certain Elizabethan ideas such as angels, devils, hell and doomsday. Shakespeare adds some supernatural phenomena on the night preceding Caesar's assassination including an earthquake, thunder, lightning and a "tempest dropping fire (I, iii, 9)" all of which allude to the cosmic disasters normally associated with the Biblical portrayal of doomsday.

In Act II, Caesar's wife Calpurnia begs him not to go to the senate because of a dream she had in which he is murdered. She then recounts some horrid sights: "A lioness hath whelped in the streets / And graves have yawned, and yielded up their dead" (II, ii, 18-19). Caesar makes a brave stand and declares that he will go anyway because "Cowards die many times before their deaths; / The valiant never taste of death but once" (II, ii, 32-33). In addition, the augurs advise Caesar to stay home because while they were performing his animal sacrifice to the gods, "They could not find a heart within the beast" (II, ii, 41). Shortly afterwards, Caesar succumbs to his wife's appeals and they decide to send Mark Antony to the senate and tell everyone there that Caesar is not feeling well. It is Brutus Decius who uses flattery to persuade Caesar to go to the senate after all by reinterpreting Calpurnia's dream and giving it a positive note.

Plutarch described some of the portents that foreshadow Caesar's assassination such as lights in the sky, bangs and crashes, flocks of birds in the forum and fiery men. An animal that Caesar sacrifices to the gods does not have a heart. Just as in Shakespeare Calpurnia has a dream wherein Caesar is killed, and after plenty of sacrifices the diviners tell him that the omens are unfavorable, so he decides to send Antony to dismiss the senate. Nonetheless, Brutus Decius convinces Caesar to go to the senate by appealing to the ruler's pride. The next day, Caesar goes to the senate and passes by the diviner who had warned him about the dangers of the Ides of March and exclaims sarcastically "Well, the Ides of March have come!" The diviner, in turn, responds 
"Yes, they have come, but they have not yet gone" (Plutarch, $1579 / 1999$, pp. 353-4). Such superstitious accounts in Plutarch indicate that even a historian like Plutarch needed to embellish his narrative with certain cultural notions derived from his background such as the widespread superstitions in Rome called "De Divinatione" (Vawter, 1981, p. 205). Plutarch resembles Shakespeare in that both of them try to accommodate their environments in their works.

Kaula (1981) drew a parallel between Caesar and the Pope as the latter was viewed in the Elizabethan age. Protestants in Elizabethan times thought of Caesar as the founder of Rome and they harbored a great deal of "antipapal sentiments" (Kaula, 1981, p. 202) because they referred to Rome as the "Whore of Babylon" (Kaula, 1981, p. 202). Cassius' attack on Caesar as a man who has attained so much power that his eye "doth awe the world" (I, ii, 123) is similar to the Protestant condemnation of the Pope for trying to become a god. In addition, Kaula (1981) clarified how the scene between Brutus and his wife Portia differs from the same episode in Plutarch. Shakespeare draws upon the Christian concept of marriage rather than the Classical one in his portrayal of the relationship between them. Portia's statement to her husband "incorporate and make us one" (II, I, 273) manifests the Christian undertones in the play.

Another incident worth comparing in the two works is Artemidorus' attempt to warn Caesar about the planned assassination. Plutarch noted that Artemidorus, who was a close friend of Brutus, got knowledge of the conspirators' scheme and wrote down a warning to Caesar on a petition scroll. Artemidorus then approached Caesar on his way into the senate and told him "Read this one yourself Caesar, and read it soon" (Plutarch 1579 / 1999, p. 355). Caesar tried to read the scroll on numerous occasions but he did not get the opportunity to do so because of the large crowds of people flocking around him.

Shakespeare dramatizes the scroll scene by having Artemidorus read its contents out loud while standing alone on the stage. Artemidorus states reading his scroll to himself:

Caesar, beware of Brutus, take heed of Cassius; come not near Casca,

have an eye to Cinna, trust not Trebonius, mark well Metellus Cimber;

Decius Brutus loves thee not.... There is but one mind in all these men,

and it is bent against Caesar....Security gives way to conspiracy....'(II, iii, 1-6)

In the play after Artemidorus moves toward Caesar and requests that he read his petition first because it "touches Caesar nearer"(III, i, 7) Caesar gallantly answers "what touches us ourself shall last be served." (III, i, 8) Unlike in Plutarch Caesar here never tries to read this warning, but takes a noble stance, appearing to put the public interest ahead of his own.

Muir (1977) remarked that the discrepancy between Plutarch and Shakeapeare in the portrayal of the above event illustrates some of the playwright's historical alterations for the sake of characterization. In the play Caesar's physical frailties are emphasized; nevertheless, he is at different intervals, like in the scroll scene, depicted as a much nobler ruler than he is in Plutarch.

Shakespeare might have tempered Caesar's image in order to make him more plausible as a tragic hero; by displaying some compassion for his people, Caesar's ultimate death arouses sympathy in the hearts of the Elizabethan audience. In addition, Shakespeare is able to create some tension that results from the dramatic irony which ensues in Caesar's exchange with Artemidorus.

\section{Caesar's Assassination Scene and the Ensuing Speeches:}

Another important event worthy of investigation in the two works is the assassination scene. In Plutarch, Casca throws the first blow with his sword but he is too disconcerted to make a fatal strike. Caesar shouts: "Damn you Casca!" (Plutarch, 1579 / 1999, p. 356). After that he is surrounded and wherever he turns he is struck in the face or in the eyes with a sword. He resists all the conspirators' blows but when he sees Brutus attacking him, he surrenders, pulling his toga over his head and falling down to the ground below Pompey's statue. Plutarch concluded by stating: 
For it is said that he was struck twenty three times, and with all these

blows raining down on a single target of their victim's body, many of the conspirators were wounded by one another as well. (1579/ 1999, p. 356)

In the play Caesar stubbornly holds his resolve and refuses to change his mind about the exile of Meteluss Cimber's brother. Unlike the events in Plutarch, Caesar here takes up a superior tone claiming that he as their supreme leader must not be moved by their appeals; quite the contrary he is "constant as the northern star" (III, i, 62). As is the case in Plutarch, Caesar is pained most when he sees Brutus attacking him and he says "Et tu Brute? Then fall Caesar." (III, I, 79) There is no mention of Pompey's statue or a description of Caesar's actions before he falls to his demise.

In Shakespeare's Political Drama Leggatt (1988) emphasized Shakespeare's use of Latin in Caesar's final words. According to Leggat this code switching transforms Caesar from "a character in an English play to a figure in Roman history, fixed at a memorable moment" (p. 154). It is of some significance to point out that this code switching is an example of how Shakespeare literally incorporates Roman history into his play. By uttering Latin words, Caesar the character is brought closer to the historical Caesar in his death scene.

Evidently, Shakespeare resorts to historical alterations in order to achieve certain dramatic effects. Muir (1977) demonstrated how the playwright molds chronology to attain "dramatic reversal" (p. 117). In Plutarch Brutus makes two speeches after the assassination, and Antony's speech comes the next day following the reading of Caesar's will. Shakespeare, on the other hand, combines Brutus's speeches into one and gives the impression that his words register successfully with the commoners. Antony gives his speech right after Brutus and the reading of the will becomes part of his funeral oration. This juxtaposing of the two contrasting speeches serves "to magnify Antony's manipulation of the citizens" (Muir, 1977, p. 117).

After Brutus delivers his speech the people's reactions reveal their ignorance, fickleness and their impressionability. First of all they miss the main point of Brutus' motive for putting Caesar to death: "...as he was ambitious, I slew him" (III. ii 24-5). Brutus firmly believes that he needed to kill Caesar for the good of Rome. Caesar had to be stopped from becoming a dictator. However, the common people cannot comprehend Brutus' words. After he finishes his speech, one of the people in the crowd shouts "Let him be Caesar!" (III. ii 24-5). They cannot grasp Brutus' concept of democracy; ironically, they want to crown Brutus even though he killed Caesar to stop him from going through with the coronation. The plebeians also exalt at Caesar's death even though they are seen celebrating his return at the beginning of the play.

By contrast, in Plutarch, the crowd makes no such reaction to Brutus' speech. According to Plutarch, 'the people listened without expressing either approval or disapproval of his [Brutus'] actions. It was clear from their lack of response that although they felt sorry for what had happened to Caesar, they also respected Brutus" (Plutarch, 1579 / 1999, p. 357). Plutarch presented events as they occurred without paying attention to any dramatic effects. In Plutarch, Antony incites the people against the conspirators, brandishing Caesar's blood-stained clothes and calling the perpetrators murderers. He also gives his speech after the reading of Caesar's will, so it seems as though the Romans were already stirred up against Brutus and the others even before hearing Antony's speech. That is why the plebeians cremate Caesar's body in a holy fire and then run to attack the assassins.

Delaney (2002) focused on another historical discrepancy in the play regarding Caesar's mantle. Antony makes use of this mantle in Caesar's funeral oration in order to stir up the people's emotions against the conspirators. Antony states that Caesar had worn this same mantle in his victory over the Nervii. This victory occurred in 57BC while Caesar's death was in 44BC. A question is raised here about the validity of Antony's claim: why would Caesar keep wearing the same mantle for thirteen years? Delaney suggests that perhaps Shakespeare takes advantage of the 
mantle for practical, theatrical purposes. The torn, bloody mantle brandished by Antony creates a "strong, visual effect" (Delaney, 2002, p. 122) especially since the audience would not see Caesar's dead body during the funeral scene.

\section{Events that Unfold after the Assassination:}

Another one of Shakespeare's changes concerns Caesar's nephew, Octavius who arrives a day after the assassination; however, in the historical account, he had arrived a few weeks later. The playwright excludes the dispute that arises between Antony and Octavius before the establishing the triumvirate with Lepidus (Muir, 1977; Okhamafe, 2009).

Plutarch narrated the events of this quarrel between Antony and Octavius wherein the core of the argument arises from fiscal concerns. Antony wishes to avoid granting every Roman citizen seventy five drachmas as was stipulated in Caesar's will, but Octavius desires to honor Caesar's wishes. Later Octavius sets up an alliance with Cicero and all the others who hate Antony. This dispute is easily resolved and Octavius meets Antony to set up the triumvirate and split up the empire amongst one another. They also decide who they should put to death. Plutarch expressed some bitterness towards the members of the triumvirate when he stated, "in the end their anger at those they hated led them to betray both the respect to their relatives and the loyalty to their friends." (1579/ 1999, p.378)

In Julius Caesar there is no such dispute, but there is a chilly scene wherein the three members of the triumvirate meet and decide who to kill and as, is the case in Plutarch, they bargain with one another over the killings of friends and family. In Plutarch there is no mention of Antony's intentions to do off with Lepidus as there is in the drama. In fact in the historical narrative Antony defeats Lepidus' army but does not kill him. Instead he treats him with respect and "although in fact he [Antony] was in total control, he reserved for Lepidus the title and prestige of imperator (Plutarch, 1579 / 1999, p. 378). In the play, on the other hand, Antony explicitly expresses his contempt towards Lepidus in a conversation with Octavius and how when Lepidus is killed, there will be more of the empire left for the two remaining members of the triumvirate. Antony tells Octavius after Lepidus leaves:

This is a slight, unmeritable man,

Meet to be sent on errands. Is it fit

The three fold world divided, he should stand

One of the three to share it? (IV, I, 11-14)

Another detail that appears in the historical narrative but not in the play is the people's reaction towards the new triumvirate. According to Plutarch the people of Rome were miserable under the rule of this triumvirate. Antony indulged in hedonistic pleasures and the triumvirs would sell the property of the people they had murdered after accusing their wives and relatives of bogus charges. Moreover, the three rulers enforced all sorts of taxes that broke the back of the common people.

An additional difference between Plutarch and Shakespeare is best manifested in the ghost scene. In the historical account Brutus is just about to move his army from Abydos to Europe, and is awake late at night worrying about what is to come. Suddenly he sees a man of unusual height and ghastly appearance. This apparition that Brutus encounters declares: "I am the spirit of your doom, Brutus and you will see me at Philippi” (Plutarch, 1579 / 1999, p. 358). Interestingly enough, Muir (1977) elucidated the modifications that Shakespeare makes to this scene. The playwright transfers the ghost from Abydos to Sardis and specifically presents this apparition as Caesar's ghost and not simply Brutus' evil spirit. Furthermore, the two battles wherein Cassius and Brutus each takes his own life are merged into one for dramatic economy. By changing the evil spirit in Plutarch into Caesar's ghost, Shakespeare achieves a form of poetic or dramatic justice. On one hand, Caesar's spirit is avenged, while on the other hand Brutus's severe guilt over killing his beloved friend is appeased. 


\section{CONCLUSION}

Shakespeare is a master at taking historical content and converting it into awe-inspiring drama. The playwright's ingenuity is quite apparent in Julius Caesar as well as in his numerous other historical dramas. From the preceding New Historicist analysis of Julius Caesar, it is clear that Shakespeare steps out of the confines of historical narrative to convey the realities of the Renaissance Age. By hybridizing history, he combines elements of Classical Rome with matters pertaining to the Elizabethan era. The New Historicist interpretation of Julius Caesar reveals how the cultural implications of Elizabethan society and Roman history are flux in nature; cultural nuances of the two ages may extend beyond their own historical context and, in turn, intermingle with various historical interpretations notwithstanding the accuracy of such historical narratives. It is through the amalgamation of Roman and Elizabethan components and the rendering of variations in history that Shakespeare can create a highly prominent play and establish a subtle critique of his society. Shakespeare's motives for the historical alterations in Julius Caesar range from dramatic economy to theatrical effects to an implicit assessment of his society's contemporary affairs, especially the British people's fear of a monarchal vacuum.

Clearly, Shakespeare is no historian; quite the contrary, he is willing to forsake historical accuracy in his quest for dramatic perfection. For the playwright, history simply becomes a canvas upon which he can paint his own narrative springing from his personal cultural experience and the cultural /historical realities that preceded him. In this sense Shakespeare contributes to the dramatic dialogue of humanity in his appropriation of historical content to represent contemporary reality and in his anticipation of the continuation of the ever-fluctuating nuances of historical narrative.

\section{References:}

Delaney, B. (2002). Shakespeare's_Julius Caesar. Explicator, 60 (3), 122-4. Retrieved from https://www.ebsco.com.

Hadfield, A. (2014). The Arden critical companions: Shakespeare and Renaissance politics. New York, NY: A\&C Black.

Hankins, J. (1978). Backgrounds of Shakespeare's thought. Sussex, England: The Harvester Press.

Gray, P. (2016). Caesar as comic antichrist: Shakespeare's Julius Caesar and the medieval stage giant. Comparative Drama, 50, (1), 1-31. Retrieved from https://www.ebsco.com.

Greenblatt, S. (2005). Renaissance self-fashioning: from More to Shakespeare. Chicago \& London: The Chicago University Press.

Jackson, D. (2000). From history to the stage: An account of Shakespeare's adaptation of Julius

Caesar. Shakespeare online. Retrieved March 22, 2010 from http://www.shakespeareonline.com/essays/fromhistorytostage.html.

Kaula, D. (1981). "Let us be sacrificers": Religious motifs in Julius Caesar. Shakespeare studies.

14. 197-215. Retrieved from https://www.ebsco.com.

Kewes, P. (2002). Julius Caesar in Jacobean England. Seventeenth Century, 17, (2), 155-

186. Retrieved from https://www.ebsco.com.

Leggatt, A. (1988). Shakespeare's political drama: The historical and the Roman plays. London: Routledge.

Meyer, J. (2014). Editing textual synergies: New Historicism and "New Textualism".

Poetics Today, 35, (4), 2, 591-613. Retrieved from https://www.ebsco.com.

Muir, K. (1977). The sources of Shakespeare's plays. London: Metheun \& CO LTD. 
O’Dair, S. (1993). Social role and the making of identity in Julius Caesar. Studies in English Literature, 1500-1900, 33, (2), 289-307. Retrieved from https://www.ebsco.com.

Okhamafe, I. (2009). Historical fabulation as history by other means: Shakespeare's Julius Caesar and Mofolo's Chaka as opposites in rubiconesque leadership. Analecta Husserliana IC, 5176. Retrieved March 22, 2010 from_c Springer Science+Business Media B.V.

Plutarch. (1999). Roman lives: A selection of eight Roman lives. (R. Waterfield, Trans.)

Oxford: Oxford University Press (Original work published in 1579).

Raspa, A. (2016). Shakespeare and the Renaissance humanist: Moral philosophy and his plays. New York, NY: Palgrave Macmillan.

Ronan, C. J. (1983). Shakespeare's Julius Caesar. Explicator, 42 (1), 11-12. Retrieved from https://www.ebsco.com.

Strier, R. (1982). Identity and power in Tudor England: Stephen Greenblatt's Renaissance self-fashioning. Boundary 2, 10, (3), 383-394. Retrieved from https://www.ebsco.com.

Shakespeare, W. (1996). Julius Caesar. New Swan Shakespeare. H.M. Hulme (ed.). Essex, England: Longman.

Vawter, M. (1976). ' After their fashion ': Cicero and Brutus in Julius Caesar.

Shakespeare studies, 9, 205-219. Retrieved from https://www.ebsco.com. 